Вєдєнєєв Д.В., доктор історичних наук, професор, провідний науковий співробітник науково-дослідного відділу науково-дослідного центру воєнної історії НУО України імені Івана Черняховського (м. Київ)

\title{
ОПЕРАТИВНО-БОЙОВА ДІЯЛЬНІСТЬ СПЕЦГРУП НАРКОМАТУ ДЕРЖАВНОЇ БЕЗПЕКИ УКРАЇНИ ПІД ЧАС ВИЗВОЛЕННЯ СХІДНОЇ СВРОПИ ВІД НАЦИЗМУ (1944-1945)
}

У статті на основі архівних документів досліджуються особливості творення та оперативно-бойової діяльності спеціальних формувань Наркомату держбезпеки Української РСР, котрі були введені 3 розвідувально-диверсійними завданнями до окупованих гітлерівиями крайн Східної Свропи. Висвітлюються організачія та комплектування згаданих спецформувань, їх завдання, розвідувальна робота в інтересах Діючої армії, диверсійна діяльність в інтересах підриву тилу й комунікацій противника. Окремо розглядається виконання завдань зі сприяння у розгортанні партизанського руху та опору патріотичними силами Східної Свропи, здійснення воєнно-політичної розвідки в інтересах створення довгострокових позичій впливу СРСР у регіоні.

Ключові слова: Друга світова війна, Східна Свропа, спецслужби, розвідка, інформачійна робота, диверсійна робота.

Постановка проблеми. Розвідувально-диверсійна та оперативнобойова діяльність за лінією фронту (“зафронтова діяльність”) упродовж війни 3 нацизмом оформилася як важливий самостійний напрям зусиль органів державної безпеки, спрямований на відсіч агресору. Завдання добування розвідувальної інформації на зайнятій противником території (включаючи території окупованих рейхом держав Східної Свропи), дестабілізації 
ворожого тилу й комунікацій викликали необхідність творення профільних підрозділів зафронтової роботи.

Суттєвим чинником визволення Східної Свропи стала оперативнобойова діяльність опергруп Народного комісаріату державної безпеки (НКДБ) Української РСР із розгортання у регіоні партизанського руху, воєнно-стратегічної та воєнно-політичної розвідки, налагодження диверсійної роботи, спецпропаганди тощо. Згадані аспекти діяльності зафронтових формувань становлять науковий інтерес для поглибленого вивчення минулого вітчизняних спецслужб, важливі з погляду акумулювання оперативно-бойового досвіду за умов становлення Сил спеціальних операцій Збройних Сил України.

Науково-документально обгрунтовані факти внеску України у визволення Східної Європи від гітлеризму сприятимуть не тільки поглибленому студіюванню маловідомих сторінок вітчизняної військової iсторії, а й формуванню позитивного іміджу України в контексті іiі євроінтеграційних спрямувань.

Стан наукової розробленості теми. Поштовх розвитку історіографії теми статті дало вивчення досвіду розвідувально-диверсійної роботи 1941-1945 рр. для удосконалення підготовки радянських спецслужб до відповідних дій у разі глобальної війни та у локальних конфліктах, де опосередковано або прямо застосовувалися сили спецоперацій СРСР (Курси удосконалення офіцерського складу з навчання співробітників КДБ до дій у складі оперативно-бойових груп на території противника; 8-й відділ Управління “С” (нелегальна розвідка) Першого головного управління (зовнішня розвідка) КДБ СРСР, що виконував науково-дослідні функції у сфері вивчення розвідувально-диверсійних дій сил спеціального призначення та готував спецрезервістів тощо) [1, с. 194]. Тому з метою підготовки до зафронтових дій в “особливий період” вийшли монографічні й навчальні праці В. Андріанова, П. Брайка, В. Боярського, Г. Сечкіна, І. Старинова, де автори серйозну увагу приділили вивченню й акумулюванню досвіду 
розвідувально-диверсійної роботи органів НКВС-НКДБ, ГРУ ГШ у період війни, фахово проаналізували організацію, форми і методи зафронтової роботи спецгруп НКВС-НКДБ [2-7].

Після введення радянських військ в Афганістан (1979 р.) у складі Вищої Червонопрапорної школи (ВЧШ) КДБ СРСР у Москві створили окрему спецкафедру “M” із викладання тактики агентурно-оперативної роботи органів держбезпеки в особливий період (передусім, на матеріалах Великої Вітчизняної війни), застосування ними специфічних партизанських та зафронтових методів роботи.

Серед профільних досліджень варто відзначити праці Я.Семенова та М. Борисова з вивчення агентурної розвідки спецформувань НКВС-НКДБ за кордоном [8], а також спеціальні праці 3 історії тих структур органів держбезпеки, що вдавалися до розвідувально-диверсійної роботи за лінією фронту [див. напр.: 10]. Варто згадати праці В. Нікітченка й О. Іванкова, котрі певною мірою узагальнили дослідження провідних напрямів оперативної роботи органів держбезпеки в Україні, включаючи боротьбу за лінією фронту [11-13]. Водночас 3'явилася новаторська праця Г. Мігрина та Г. Міщенка 3 історії розвідувальної роботи партизанів України, де давався аналіз сил і засобів, форм і методів розвідроботи в інтересах фронту, звільнення України та Європи від нацистів [14].

На сьогодні одним із найбільш грунтовних досліджень ролі НКВСНКДБ в організації партизанського рух є монографія О. Попова [15], у якій чимало уваги відведено ролі органів НКВС-НКДБ у розгортанні спеціальної діяльності за лінією фронту. Серед сучасних наукових здобутків із теми дослідження варто назвати капітальну працю В. Боярського [16]. У ній на підставі грунтовного фактичного матеріалу розглянуто функції спецслужб із організації зафронтової боротьби на основі партизанських формувань, проведення розвідувально-диверсійних операцій, виходячи із досвіду України. 
В українській радянській історіографії виділяється монографія А. Кентія та I. Кураса з історії Українського штабу партизанського руху (УШПР), у якій, спираючись на солідний архівний матеріал, дослідники висвітлили розвідувально-диверсійну роботу штабу у взаємодії зі спецслужбами [17], праця М. Старожилова [18], у якій при дослідженні організації партизанських з'єднань порушено й аспект їх спеціальної діяльності. Відсутність належних відкритих праць щодо утаємничених моментів зафронтової діяльності НКВС-НКДБ певної мірою компенсувалася виходом монографії Г. Куманьова й А. Чайковського щодо провідних напрямів оперативно-бойової діяльності органів держбезпеки в Україні [19].

Нові горизонти у дослідженні проблеми з'явилися у науковців України після відкриття відповідних архівних фондів, переосмислення складних питань військової історії України доби Другої світової війни. Передусім, відзначимо монографію знаних дослідників історії партизанства та повстанських рухів в Україні А. Кентія та В. Лозицького “Війна без пощади і милосердя” [20]. У ній на основі великого масиву розсекречених архівних матеріалів виокремлено такі аспекти, як розвідувальна, диверсійна робота партизанів, гострі проблеми законності та контррозвідувального забезпечення партизанських формувань 3 боку спецслужб, терористична практика по відношенню до колабораціоністів тощо. Роль НКВС-НКДБ УРСР, ГРУ ГШ Червоної армії у розгортанні та оперативному забезпеченні партизанського руху висвітлена у монографії О. Гогуна [21] та науководокументальному виданні, підготовленому разом із В. Лозицьким [22; див. також: 23].

Виклад основного матеріалу. Серйозні прорахунки і втрати під час організації партизанської та розвідувально-диверсійної роботи на окупованій території на першому етапі війни призвели зокрема до необхідності створення окремого підрозділу спецслужби, що зосередив би у своїх руках важелі управління (координаціі) спеціальною діяльністю за лінією фронту та з позицій партизанських формувань. 18 січня 1942 р. у складі НКВС СРСР 
організували 4-те Управління (зафронтова робота; із відтворенням Наркомату державної безпеки СРСР у 1943 р. цей підрозділ перейшов до складу НКДБ СРСР та союзних республік). "Руйнування тилів ворога та організація агентурної розвідки на окупованій противником територіі” - так у службових документах стисло визначалася місія зафронтового управління [24, спр. 86751, т. 46, арк. 1]. Оперативними співробітниками укомплектували розвідувальний відділ УШПР та оперчастини партизанських формувань.

Після утворення 4-го Управління НКВС СРСР були уточнені завдання спецпідрозділу 3 зафронтової роботи та визначено функціональну спрямованість його апарату. Затверджене наказом НКВС СРСР від 1 червня 1942 № 001124 “Положення про роботу 4-х відділів НКВС-УНКВС республік, країв і областей” серед провідних завдань спецпідрозділу визначало:

створення нелегальних резидентур у населених пунктах на окупованій території та забезпечення надійного зв'язку з ними;

відновлення взаємодії із найбільш цінною та перевіреною агентурою на окупованій території;

запровадження агентури в розвідувальні, адміністративні органи противника та антирадянські організації;

підбір та перекидання за лінію фронту кваліфікованої агентури та просування іiі до Німеччини та інших європейських країн;

формування та направлення за лінію фронту розвідувальнодиверсійних груп, маршрутної агентури;

забезпечення зафронтових формувань зброєю, диверсійними засобами, засобами зв'язку тощо.

Спочатку у складі 4-го Управління НКВС УРСР перший відділ займався розвідувально-диверсійною роботою на теренах країн-сателітів Німеччини або окупованих нею країн Східної Свропи. Позитивні зміни у становищі на фронтах, міжнародній та військово-політичній обстановці в СРСР, поступове звільнення окупованої території призводили і до корегування функцій та 
структури 4-го Управління, тепер уже у складі НКДБ УРСР. Відповідно до затвердженого 16 жовтня 1943 р. положення, функції відділів Управління визначалися так:

- перший відділ: керівництво оперативними групами у тилу противника, запровадження агентури в розвідувальні й контррозвідувальні органи, адміністративно-політичні установи противника на окупованій території, створення оперативних позицій у підпіллі ОУН, у Російській визвольній армії, робота у середовищі “церковників і сектантів”;

- другий відділ: організація диверсійно-терористичної роботи, ведення розслідування фактів зради агентури 4-го Управління, допит військовополонених, керівництво 4-ми підрозділами УНКДБ;

- третій відділ: матеріально-технічне забезпечення агентурнооперативної роботи, оперативний облік, інформаційна робота, оперативна техніка та виготовлення документів прикриття.

Судячи із наявних звітних матеріалів, на завершальному етапі війни організацією та введенням спецформувань у тил противника (переважно за кордон) займався 3-й відділ (начальник - майор Єфремов, три відділення, 28 штатних посад) [24, спр. 83529, ч. 1, арк. 18-21].

До основних видів власне зафронтових оперативних формувань НКВСНКДБ відносилися:

- агентурно-оперативні групи (3-5 агентів органів держбезпеки, які пройшли певну підготовку для дій у близькому тилу з розвідувальними завданнями);

- оперативно-чекістські (розвідувально-диверсійні) групи (5-8 кадрових співробітників держбезпеки, які виводилися за лінію фронту для організації розвідувально-диверсійної роботи 3 позицій, як правило, партизанських загонів);

- оперативно-чекістські групи спеціального призначення (10-15 i більше співробітників НКВС-НКДБ, виведених на територію іноземних держав для виконання спеціальних розвідувально-диверсійних завдань); 
- оперативно-чекістські бази або загони (озброєні загони 3 кадрових співробітників, агентів спецслужби, партизанів, чисельність до 100 і більше осіб, які вели активну диверсійно-терористичну боротьбу на комунікаціях, проти важливих об’єктів противника, слугували основою для формування партизанських сил тощо).

Опергрупи, як правило, включали офіцера-командира, його заступника з розвідувально-диверсійної роботи, комісара, 1-2 радистів-шифрувальників, медпрацівника, оперативних працівників, перевірених агентів, які пройшли диверсійну та іншу спецпідготовку. Загалом НКВС-НКДБ УРСР за роки війни створили 135 подібних формувань (7500 учасників) [11, с. 17].

Інтереси забезпечення стратегічного наступу Червоної армії обумовили надання навесні 1944 p. завдання 28 опергрупам НКДБ УРСР передислокуватися на захід для розвідувально-підривної роботи в тилу противника й сприяння наступаючим військам. Групи швидко обростали волонтерами з місцевих мешканців, вели вербувальну роботу, створювали на своїй базі партизанські загони. Так, група "Ракета" до березня 1945 р. виросла до 700 бійців, провела 103 диверсійні та бойові акції [9, с. 126-127].

На базі окремих опергруп за рахунок поповнення патріотамиантифашистами країн Східної Європи виростали партизанські бригади, спроможні до результативних бойових дій. У 1944 р. частину сил спеціального призначення НКДБ УРСР - 53 опергрупи (780 бійців), а також 759 агентів-одинаків вивели на терени Польщі, Словаччини, Чехії, де вони допомагали патріотичним силам боротися проти окупантів. Зокрема, 19річний офіцер НКДБ УРСР М. Радул відзначився як командир багатонаціональної партизанської бригади на території Чехословаччини. Опергрупа М. Осіпова виросла до партизанського загону у 1 тис. людей, знищивши понад 600 противників, 26 ешелонів, 17 мостів тощо [2, с. 7].

Спецформування одразу енергійно включилися у забезпечення наступу радянських військ. Так, група "Волинці", незважаючи на значні втрати і поневіряння, здобула інформацію про зручні для проходу військ перевали 
Карпат і сили угорської армії, фортифікаційні лінії противника [див.: 24, спр. 28442]. У жовтні 1944 р. бригада, утворена на базі опергрупи “Мисливці" та поповнена партизанами-чехами і словаками, упродовж 2 діб спільно 3 військами утримувала стратегічний перевал Бескид до підходу основних сил 4-го Українського фронту. На прохання командування 1-го Українського фронту опергрупи сприяли захопленню Сандомирського плацдарму для розвитку наступу на територію Польщі, опергрупа “Вісла" встановила зв'язок із польським патріотами-антифашистами та передавала від них цінну розвідувальну інформацію 1-й гвардійській армії. Згодом, за зверненням армійського командування, опергрупи зосередили зусилля на диверсійних акціях: $з$ липня 1944 до січня 1945 р. лише в Польщі здійснено 114 підривів залізничних мостів та 5 військово-промислових об'єктів [24, спр. 83510, арк. 83-84; спр. 86704, т. 2, арк. 169-176].

Безперечно, першочерговим завданням спецформувань НКДБ УРСР слугувала розвідувальна робота. Головним інструментом здобуття цінних відомостей слугували створені зафронтовою розвідкою агентурноінформаційні мережі. Зокрема, співробітники спецгрупи О. Святогорова “Зарубіжні” у Чехословаччині залучили до співробітництва з числа місцевих антифашистів 9 резидентів, 89 агентів, 12 інформаторів (67 негласних джерел продовжили співпрацю і після завершення війни) [24, спр. 86751, т. 18, арк. 60, 138].

Окремі спецформування та агенти-одинаки отримували специфічні завдання, повязані зі збиранням воєнно-політичної інформації. Група "Вісла" зібрала відомості й підготувала доповідь про діяльність Армії Крайової, Батальйонів хлопських, політичних партій Польщі [24, спр. 86751, т. 8, арк. 48]. Спецгрупа “Словяне”, виведена в Болгарію, зібрала інформацію про воєнізовані білоеміграційні організації, “Партію монархічного обєднання”, “Воєнно-монархічний союз” [24, спр. 86751, т. 15, арк. 26]. Значними здобутками відзначилася у цій царині спецгрупа “Дружба” М. Онищука (“Баглія”). Її розвідники завербували понад 30 оперативних джерел i 
підготували цінні інформаційні зведення про армію Власова, “Військо Донське" на службі у рейха, польські націоналістичні організації, формування УПА, підпілля ОУН та криваве українсько-польське протистояння на Волині, Білоруської Центральної Ради тощо [24, спр. 86751, т. 13]. НКДБ УРСР ставив і завдання щодо ліквідації високих представників німецького командування, окупаційної адміністрації, колабораціоністів, а також значущих фігур антирадянських політичних організацій за кордоном. Зокрема, спецгрупа 4-го Управління НКДБ УРСР “Валька” (окрім завдання 3 ліквідації німецького генерал-губернатора Польщі Франка) була скерована на виявлення й розробку емісарів польського еміграційного уряду. Агенти "Північна" та "Віолетта", виведені у Німеччину, отримали завдання увійти до оточення та ліквідувати “Ворона” (А. Власова) [24, спр. 86751, т. 7, арк. 4, $14-15,22-23]$.

Окремо варто наголосити, що під час виконання визвольної місії у країнах Східної Європи 34 спеціальні формування НКДБ СРСР та УРСР здобули значний масив інформації, важливої для Діючої армії й планування наступальних операцій. Зокрема, на основі агентурно-оперативних даних вони підготували 167 важливих інформаційних зведень, з яких 50\% були в інтересах Центру (Генштабу Червоної армії, керівництва спецслужби тощо), $32 \%$ - для Діючої армії, 13\% повідомлень містили значущу політичну інформацію, а також кілька десятків зведень контррозвідувального характеру. Серед винятково важливих 3 воєнно-політичного погляду повідомлень - здобута опергрупою “Вірні” інформація про затримання у Чехословаччині англо-американської розвідувальної групи 318 осіб, закинуту туди зі спецзавданням для підготовки переходу цієї держави під політичний контроль Лондона у післявоєнний період [8, с. 72-74, 81-82], докладні повідомлення про масове знищення мирного населення й військовополонених у таборах смерті в Польщі.

У цілому, за роки війни на основі здобутих 4-м Управлінням НКВСНКДБ УРСР розвідувальних відомостей було підготовлено 
355 інформаційних документів, яким користувалися в НКДБ СРСР та Генеральному штабі Червоної армії [24, спр. 86751, т. 46, арк. 35]. Загалом за роки війни органи держбезпеки вивели за лінію фронту 2222 оперативні групи (з яких НКВС-НКДБ УРСР сформували 677). Від них було отримано 4418 цінних розвідувальних повідомлень про становище за лінією фронту, 3 яких 1358 направили до Генерального штабу Червоної армії, 420 командуванню фронтів, 629 - командуванню авіації далекої дій для завдання бомбових ударів [25, с. 90].

Визначну роль опергрупи з України відіграли в останні дні війни, особливо у ході Празького повстання 5-9 травня 1945 р. До 9 травня 1945 р. тільки в Чехословаччині діяли 21 партизанська бригада і 13 окремих загонів, створених органами держбезпеки УРСР. У Празькому повстанні травня 1945 р. взяло участь сім українських опергруп - “Шквал”, “Ураган”, “Вперед” та інші. Завдяки їм Генштаб Червоної армії мав правдиві відомості про перебіг повстання у різних містах Чехословаччини. Група “Смолоскип” відзначилася у Добржинському та Пршибранському антифашистських повстаннях. Група “Вперед” у переможний день 9 травня 1945 р. сміливо вступила у переговори, змусила до капітуляції та роззброїла дві відступаючі угорські дивізії. Їхні колеги зі “Смолоскипу” захопили начальника штабу “власівської” РВА генерал-майора Трухіна [24, т. 46, арк. 21; 26, с. 17-18].

У цілому, під час виконання завдань на теренах Східної Свропи (лише у жовтні 1944 - січні 1945 рр.) опергрупи НКДБ УРСР знищили та знешкодили 7729 вояків противника, 16 командирів високого рангу та чиновників окупаційної адміністрації, знищили 4 військові заводи, 71 міст, 109 ешелонів, 103 автомашини тощо. Крім того, опергрупи збирали відомості про військових злочинців, активних колабораціоністів, агентуру спецслужб противника. Одна лише група “Вірні” виявила 90 німецьких агентів, 783 яких - словацького пронацистського режиму Тіссо, а також 207 активних карателів тощо [8, с. 83]. За період війни формування 4-го Управління НКВСНКД УРСР втратили убитими 489 осіб. та безвісти зниклими 271 особу, і 3 
153 радистів при виконанні завдань в тилу противника загинуло 42 [24, спр. 2944, т. 1, арк. 210-227].

Висновки. На завершальному етапі війни в інтересах сприяння наступу радянських військ та піднесенню руху опору в окупованих нацистами країнах Східної Європи було задіяно систему зафронтової розвідувальнодиверсійної діяльності у складі іï управлінського осередку та мережі кваліфікованих оперативних груп, учасники яких отримали спеціальну підготовку (у т.ч. у Школі особливого призначення УШПР) та досвід партизанської боротьби піж час визволення України. Згадані формування виступили оргядром для поширення партизанства й “малої війни” у Східній Європі. Налагоджена органами державної безпеки система розвідувальної та контррозвідувальної роботи з позицій партизанського руху стала помітним чинником бойових успіхів Червоної армії із вигнання агресорів зі Сходу Європи та Балкан.

Було завдано відчутних ударів по комунікаціях та об'єктах ВПК агресора, органах його військового управління, проведено акції із розкладення його допоміжних формувань та армії маріонеткової Словаччини. Діяльність зафронтових оперативних груп під час визволення народів Східної Європи сприяла розвідувальному забезпеченню Діючої армії, консолідації антифашистських і патріотичних сил регіону, розгортанню партизанського руху (насамперед, організації його розвідувальної роботи та контррозвідувального захисту), підриву військово-економічного потенціалу противника та результативності антигітлерівських збройних повстань, а також розшуку військових злочинців.

Силами опергруп було здійснено низку важливих оперативних заходів, в тому числі із формування агентурної мережі та позицій політичного впливу в управлінських і партійно-політичних колах суміжних держав, що у процесі післявоєнного врегулювання сприяло справі міжнародно-правового оформлення соборності етнічних українських земель й підвищенню міжнародного статусу Української РСР як члена ООН. 


\section{Список використаних джерел і літератури}

1. Дроздов Ю.И. Записки начальника нелегальной разведки. - М. : ОЛМА-ПРЕСС, 2000. - 416 с.

2. Андрианов В.Н. Зафронтовая работа органов государственной безопасности. - М. : ВКШ КГБ СССР, 1989. - 248 с.

3. Боярский В.И. Партизанская борьба в годы Великой Отечественной войны и участие в ней органов и войск государственной безопасности. - М. : Краснознаменный институт повышения квалификации офицерского состава Пограничных войск КГБ СССР, 1991. - Ч. 1. - 291 с.: Ч. 2. -243 c.

4. Брайко П.Е., Старинов И.Г. Партизанская война. - М. : В/ч 64510, 1983. - Ч. 1. - 335 c.

5. Зафронтовая работа оперативных групп органов государственной безопасности. - М. : ВКШ КГБ СССР, 1989. - 217 с.

6. Сечкин Г.П. Советские Пограничные войска в Великой Отечественной войне 1941-1945 гг. и возможные их действия в современных операциях. - М. : Воениздат, 1976. - 976 с.

7. Старинов И.Г. Подготовка партизанских кадров. Научнопрактическое пособие. - М. : В/ч 33965, 1989. - 116 с.

8. Семенов Я.Ф. Некоторые вопросы агентурной разведки оперативных групп органов государственной безопасности в тылу противника на территории сопредельных с СССР стран в годы Великой Отечественной войны (1941 - 1945 гг.) // Труды ВКШ КГБ СССР. - 1985. № $35 .-$ С. $70-84$.

9. Борисов Н. Оперативные группы во вражеском тылу // Сборник КГБ СССР. - 1968. - № 4. - С. 124-132.

10. Коровин B.B. Органы государственной безопасности в годы Великой Отечественной войны 1941-1945 гг. - М. : РИО ВКШ КГБ СССР, 1980. $-48 \mathrm{c}$. 
11. Иванков А.В. Из опыта работы чекистов Украины в период борьбы с немецко-фашистскими окупантами // Сборник Высших курсов. - К., 1985. № 13 . - C. 14-23.

12. Иванков А.В. Деятельность органов государственной безопасности Украинской ССР в годы Великой Отечественной войны (1941 - 1945 гг.) : Автореф. дисс. канд.юрид.наук. - М. : ВКШ КГБ при СМ СССР, 1983. - 26 с.

13. Никитченко В.Ф. Чекисты Украины в период Великой Отечественной войны // Труды ВКШ КГБ при СМ СССР. - 1971. - № 2. C. $66-82$.

14. Мищенко Г.П., Мигрин Г.П. Задача особой важности (Партизанская разведка. 1941 - 1945 гг.). - К. : Вища школа, 1985. - 206 с.

15. Попов А.Ю. Диверсанты Сталина. Деятельность органов госбезопасности СССР на оккупированной советской территории в годы Великой Отечественной войны. - М. : ОЛМА-ПРЕСС, 2004. - 405 с.

16. Боярский В.И. Партизанство вчера, сегодня, завтра. - М. : Граница, 2003. $-479 \mathrm{c}$.

17. Курас И.Ф., Кентий А.В. Штаб непокоренных (Украинский штаб партизанского движения в годы Великой Отечественной войны). - К. : Политиздат Украины, 1988. - 330 с.

18. Старожсилов Н.В. Партизанские соединения Украины в Великой Отечественной войне. - К. : Вища школа, 1983. - 237 с.

19. Куманев Г.А., Чайковский А.С. Чекисты стояли насмерть. - К. : Политиздат Украины, 1986. - 237 с.

20. Кентій А., Лозищький B. Війна без пощади i милосердя: партизанський фронту тилу вермахту в Україні (1941-1945). - К. : Генеза, 2005. $-408 \mathrm{c}$.

21. Гогун A. Сталинские коммандос. Украинские партизанские формирования. Малоизученные страницы истории. - М. : Центрполиграф, 2008. -477 c. 
22. “Создавать невыносимые условия для врага и всех его пособников...”. Красные партизаны Украины, 1941-1944: малоизученные страницы истории. Документы и материалы / Авторы-составители А. Гогун, А. Кентий. - К. : Украинский издательский союз, 2006. - 430 с.

23. Лісов О.С. Новітня вітчизняна історіографія діяльності розвідки та контррозвідки в Україні у 1917-1991 роках : автореф. дис. ... канд. істор. наук : 20.02.22 / Академія СБ України. - К. : НУОУ імені Івана Черняховського, 2017. $-20 \mathrm{c}$.

24. Галузевий державний архів (ГДА) Служби безпеки України (СБУ), ф. 60 .

25. Федорчук В. Советская военная контрразведка в годі Великой Отечественной войны // Сборник КГБ при СМ СССР. - 1970. - № 1. C. 87-98.

26. 3 архівів ВУЧК-ГПУ-НКВД-КГБ. - 2000. - № 1. - 398 с. 
Viedienieiev D.V., Doctor of Historical Sciences, Professor, Leading Researcher of Research Division of Research Center of Military History of Ivan Cherniakhovskyi National Defense University of Ukraine (Kyiv)

\section{THE OPERATIVE-COMBAT ACTIVITY OF THE SPECIAL GROUPS OF UKRAINIAN PEOPLE'S COMMISSARIAT FOR STATE SECURITY DURING THE EXEMPTION OF THE EASTERN EUROPE FROM NAZISM (1944-1945)}

The article based on the archive documents explores the features of the creation and operative-combat activity of the special formations of Ukrainian SSR People's Commissariat for State Security, which were set aside to the occupied by Nazis states of Eastern Europe with the intelligence-sabotage mission. The author highlights the organization and equipment of these formations, their mission, intelligence work for the armies interest, sabotage activity aimed to undermine the rear and enemies communications. In particular the author presents the tasks performance with the aim to create the long-term positions of the USSR's influents in the region.

Keywords: World War II, Eastern Europe, special services, intelligence service, informational work, sabotage work. 